at the average rate of 0.32 per cent. for a change of I in the sunspot number. As this is about the same average rate of change shown by the potential-gradient observations at the same two observatories, the present indications are that the average rate of change for several stations of the atmospheric-electric conductivity with sunspottedness, if not zero, is small. The continuous observations of negative electric conductivity at the Potsdam Observatory likewise indicate but little change with changing solar activity. (Since this paper was prepared it has been found, by a method ${ }^{7}$ which minimises the effect of uncontrolled changes in the factor to reduce potential gradients to volts per metre over level ground, that the average value of $s$ for the Potsdam observations from 1913-1923 was +0.27 per cent. of the mean value of the potential gradient, i.e. the potential gradient increased, on the average, with increasing sunspot activity. Accordingly, the vertical conduction current at Potsdam also increased during I9I3-I923 at the average rate of about 0.27 per cent. for an increase of $x$ in the sunspot number.)

\section{AtMospheric Electricity AND} Terrestrial Magnetism.

The foregoing results indicate a close correspondence between such changes in atmospheric electricity and terrestrial magnetism as may be dependent upon the state of the sun's activity from cycle to cycle. However, the close correspondence between the two different geophysical phenomena also holds in other respects. For example, the so-called " earth-effect" on sunspottedness during circumminimum years, the diurnal range of the atmospheric potential gradient, the diurnal range of the potential gradient of earth currents, the aurora borealis frequency for latitudes $5 \mathrm{I}^{\circ}$ to $58^{\circ}$ north, and terrestrial magnetic activity all pass through a double periodicity during the year; the maxima and minima occur near the equinoctial and solstitial months respectively. Furthermore, the retardation of the second maximum from September to October is common to all phenomena. For further explanation, reference must be made to the fuller publication. ${ }^{8}$

It would appear that terrestrial magnetism and fine weather atmospheric electricity are more closely associated than has heretofore been thought to be the case. Besides

See Terr. Mag., vol. 29 (r924), p. r8r.

Terr. Mag., vol. 29 (1924), pp. I75-179. being subject to diurnal change, they both show similar fluctuations from year to year and from month to month. Whether atmospheric electricity, like terrestrial magnetism, is subject to a still longer cycle of changes than that of the sunspot cycle, seems not unlikely, and is the subject of further inquiry.

In a notable respect the changes of atmospheric electricity differ from those of terrestrial magnetism, namely, as regards relative magnitude. The periodic variations of the earth's magnetic elements are usually but fractions of $\mathrm{I}$ per cent. of the respective element, whereas in atmospheric electricity the diurnal and annual ranges, even for undisturbed conditions, may be of the same order of magnitude as the normal potential gradient itself. If such large percentage changes as Ioo, for example, are likely to occur in the potential gradient during the day and the year, it should not be surprising if there is, on the average, a 30 per cent. change between the years of minimum and maximum sunspottedness.

\section{Is the Sunspot Influence Direct or Indirect ?}

While it may appear reasonable that atmospheric electricity does vary with solar activity, it is not possible to decide from a priori considerations whether the potential gradient ought to be high or low for maximum sunspottedness, as this depends on the modus operandi of the cause, the avèrage sign of the electrically charged particles shot out from the sun, and whether the action is a direct or an indirect one. These are questions that must be reserved for future investigation. So much interest has now been aroused in the subject that we may confidently look forward to a more careful control in future of atmospheric-electric measurements than has at times been the case, and to a wider distribution of first-class observing stations.

In conclusion, it will be of interest to refer to the fact that while the present investigation has had to be based almost entirely on the atmospheric-electric data at observatories in western Europe, the final values of the potential gradients observed aboard the Carnegie, in all oceans, show that the mean value of the potential gradient for $\mathrm{r} 9 \mathrm{I} 7$, the year of sunspot maximum, was about 20 per cent. greater than the mean value in $\mathrm{r} 92 \mathrm{I}$, near the year, 1923, of sunspot minimum. This result corresponds well with the average corresponding change at the western European observatories.

\title{
Obituary.
}

Prof. A. Dendy, F.R.S.

P ROF. ARTHUR DENDY, whose death occurred on March 24, in King's College Hospital, at the age of sixty years, was educated at the Manchester Grammar School. On leaving school he proceeded to the Owens College, where he became one of a small band of distinguished zoologists trained by the late Prof. A. Milnes Marshall. He was the first of the students of the old Victoria University to gain a place in the honours school of zoology. Soon after he took his degree in $\mathbf{1 8 8 5}$, he went to the Biological Station at Millport, and as a result of the work he did there he published his first two papers, one on a twelve-armed specimen of Antedon and the other on the regeneration of the visceral mass of the same crinoid.

Although Dendy never lost his interest in the group of Echinodermata, it was for his wide knowledge and brilliant researches on sponges that he was destined to become a world-wide authority. $\mathrm{He}$ was called to London as an assistant in the British Museum (Natural History), and undertook to complete for publication the memoir on the monaxonid sponges of the Challenger expedition, which had been left unfinished owing to the serious illness of Mr. Stuart Ridley. He set to work with his characteristic energy and skill, and this " highly satisfactory" memoir was published in 1887 . 
In the following year Dendy was appointed lecturer in zoology in the University of Melbourne, a post he held until I894, when he was promoted to the professorship in the same subject in the Canterbury College of New Zealand.

In the rich and extremely interesting fauna of Australasia, Dendy found full scope for his brilliant abilities in zoological research, and he published in rapid succession a long series of papers on the anatomy and development of some of the most interesting animals of that region. Apart from some excellent papers on sponges, he wrote on land planarians, on the land nemertine (Geonemertes), on the remarkable polyzoan Cryptozoon, on Holothurians, and on the Collembola. His valuable papers on the oviparous species of Peripatus greatly enriched our knowledge of this extremely interesting and archaic arthropod, and his study of the pineal eyes of the New Zealand lamprey Geotria threw important light on the history of these remarkable vestigial structures previously discovered in Sphenodon by his friend--also an old OwensianSir Walter Baldwin Spencer. On reaching New Zealand he lost no time in going in search of Sphenodon itself, and, on finding that there was serious danger that the enterprise of collectors would lead to its early extinction, he made urgent and successful appeals to the Government to pass measures for its protection. He was the first to write an account of the development of this reptile, and to record many important features of its anatomy and natural history.

In 1902 Dendy came back to England on a visit, and was given the hospitality of the Zoological Department of his old University in Manchester to enable him to pursue some investigations on which he was engaged. Here he completed his description of the aberrant floating hydroid Pelagohydra and examined sections through the brain of the Ammocoetes larva. In studying the anatomy of the Geotria in New Zealand, he had discovered a pair of ciliated grooves lying beneath the posterior commissure of the brain, and he found these grooves to be even better developed in the brain of the young Petromyzon. On these researches he published an interesting paper, which appeared in the Proceedings of the Royal Society in rgoz. His studies on these brains led him to the investigation of another structure in the nervous system of vertebrates, namely, Reissner's fibre. On this subject, also, he made a very important communication to the Royal Society in rgro.

While he was in England on this visit, Dendy heard of the vacancy in the chair of zoology at Cape Town. He applied for the post and was appointed. But he remained in South Africa only two years, as he received the appointment to the professorship in King's College, London, in 1905 , vacated by the retirement of the late Prof. F. J. Bell. He held this chair until his death. He was elected a fellow of the Royal Society in I908.

In London Dendy carried on his teaching and researches with increasing energy and success, and under his guidance King's College soon became recognised as an active centre of research in his subject. He put together some of his teaching notes in the form of a book entitled "Outlines of Evolutionary Biology," which was published in 1912 and has already reached a third edition, and he also wrote an interesting little book entitled " The Biological Foundations of Society," which was published in I 924 .

The last important work he wrote was the memoir on the Antarctic sponges reviewed in Nature of March 7 , p. $33^{\circ}$, but a preliminary note published in these columns on February 7 showed that he had in hand a paper in which he was prepared to maintain the rather startling proposition that the spicules of siliceous sponges are formed by the skeleton-forming cells enveloping migratory symbiotic organisms resembling micrococci. Many of his friends looked forward with much interest to the fulfilment of his promise made last December to maintain this thesis at the next meeting of the British Association.

Dendy was a man with a very striking and impressive personality, a fine speaker, and a clear and sympathetic teacher. His father was a well-known Unitarian minister. One of his sisters, Miss Mary Dendy, is widely known for her philanthropic work, particularly in connexion with the care and education of feebleminded children. Another sister married Dr. Bernard Bosanquet, and is herself a well-known writer.

$$
\text { S. J. H. }
$$

WiтH the sudden and untimely death of Prof. Dendy, we have lost the only man in England with a catholic knowledge of sponges, and probably the leading authority of the two or three in the world who could be classed with him. $\mathrm{He}$ was a biologist with wide scope of learning and research as well as a spongologist, but it is of his work on sponges only that I am competent to write.

A catalogue of Dendy's papers on sponges would be long. They begin in I886, when he was twenty-two, with Ridley and Dendy's "Preliminary Report on the Monaxonida . . . Challenger" ; they end with a letter, unseen by me as I write this (March 26), which appears in NATURE for March 28, and shall remain in these columns unanswered. Ridley and Dendy's classic Challenger monograph (I887) was written as to some five-sixths by Dendy, a wonderful piece of work for so young a man. Then came careful anatomical and histological studies of single species (Q.J.M.S., I888 et seqq.). Beside them the "Monograph of the Victorian Sponges ... Homocœla" (I89I) described several important new forms, of some of which we have little added information-one is now recognised as of generic rank by the name Dendya, not conferred by its discoverer. But the contemporary importance of the "Monograph" was that it carried on Poléjaeff's revolt (Challenger "Calcarea," r883), and struck loose from Haeckel's "Kalkschwämme," and in this it was followed by "Observations ... and Classification of the Calcarea Heterocœla" (1893, Q.J.M.S.), which made a serious and valuable attempt at classification de novo.

It would be a long article which should follow Dendy from youth to maturity and from maturity to the admirable work of his last years ; we may say briefly that Vosmaer's "Bibliography" to r9I3 (in press) gives him thirty-five publications, mainly before I 898 , and that his masterly "Reports" since $\mathrm{x} 9 \mathrm{I} 3$ on collections of sponges add up to 460 quarto pages of print. They are all good. As in other descriptive monographs, there is much which is only readable to the colleague whose interest has been aroused in the 